\title{
DETERMINAN RISIKO PEMBIAYAAN PADA BANK UMUM SYARIAH DI INDONESIA
}

\author{
Cici Widya Prasetyandari \\ Fakultas Ekonomi dan Bisnis Islam, Universitas Islam Zainul Hasan \\ Genggong Probolinggo \\ Email: ciciwidyaprasetyandari@gmail.com
}

\begin{abstract}
Financing risk is a risk inherent in bank financial institutions, this risk comes from the failure of customers to fulfill their obligations to the bank. The purpose of this study is to determine the factors that affect the risk of financing at Islamic Commercial Banks (BUS) in Indonesia. Financing risk is measured by Non Performing Financing (NPF) which acts as the dependent variable, while the independent variables used are Operating Expenses to Operating Income (BOPO), Financing to Deposit Ratio (FDR) and Capital Adequacy Ratio (CAR). The population used was all BUS in Indonesia, while the sample selection technique used the perposive sampling method, and obtained 6 BUS that met the criteria. The analytical method used is multiple linear regression analysis. The results showed that the factors that influence NPF are the ratio of OEOI and CAR.
\end{abstract}

Keywords: NPF, BOPO, FDR, CAR

\section{PENDAHULUAN}

Perbankan merupakan lembaga yang berperan dalam menyeimbangkan perekonomian masyarakat Indonesia. Bank menjalankan perannya sebagai lembaga intermediasi atau 
perantara antara pihak yang kelebihan dana dan pihak yang kekurangan dana. Bank menghimpun dana dari masyarakat dalam bentuk tabungan, deposito, dan giro, kemudian menyalurkannya kembali kepada masyarakat dalam bentuk pembiayaan.

Lahirnya bank syariah di Indonesia pada tahun 1992 merupakan suatu kebutuhan mendasar bagi sebagian besar masyarakat indonesia. karena mayoritas masyarakat Indonesia adalah beragama Islam. Bank syariah merupakan lembaga keuangan yang mengharamkan segala bentuk transaksi riba. dalam menghasilkan keuntungan, bank ini menggunakan sistem bagi hasil sesuai dengan tuntunan Alqur'an dan Hadist. Kehadiran bank syariah di Indonesia merupakan sebuah solusi yang ditawarkan kepada masyarakat agar mereka terhindar dari segala bentuk riba.

Perkembangan bank syariah indonesia berkembang sangat pesat hingga saat ini. Hal ini dapat kita lihat dari jumlah kantor cabang (KC) dan kantor cabang pembantu (KCP) yang terus bertambah setiap tahunnya. Peningkatan jumlah tersebut mengidentifikasikan bahwa masyarakat menerima kehadiran bank syariah dan percaya untuk bertransaksi di bank umum syariah. Data statistik bank umum syariah tahun 2017-2020 dapat dilihat pada tabel 1.

Tabel.1 Data Statistik Bank Umum Syariah tahun 2018-2020

\begin{tabular}{|lcll|}
\hline Tahun & Jumlah bank & KC & KCP \\
\hline $\mathbf{2 0 2 0}$ & 14 & 488 & 1351 \\
\hline $\mathbf{2 0 1 9}$ & 14 & 480 & 1243 \\
\hline $\mathbf{2 0 1 8}$ & 14 & 478 & 1199 \\
\hline $\mathbf{2 0 1 7}$ & 13 & 471 & 1176 \\
\hline
\end{tabular}

Sumber: Statistik Ojk (data diolah)

Perkembangan perbankan tentunya tak lepas dari berbagai risiko yang yang melekat pada lembaga keuangan 
bank. Risiko yang paling sering dihadapi oleh bank adalah risiko pembiayaan. Risiko pembiayaan adalah risiko yang disebabkan oleh tidakmampuan para debitur dalam memenuhi kewajibannya sebagaimana yang dipersyaratkan oleh pihak kreditur (Fahmi, 2014:104) ${ }^{1}$. Risiko pembiayaan muncul ketika nasabah yang meminjam dana kepada bank, tidak dapat membayar angsuran sebagaimana yang sudah di sepakati pada awal kontrak. Pengukuran risiko pembiayaan dapat menggunakan rasio non performing financing (NPF).

Faktor-faktor yang menimbulkan adanya risiko pembiayaan salah satunya adalah risiko operasional perusahaan. risiko ini dapat diukur dengan menggunakan rasio beban operasional terhadap pendapatan operasional (BOPO). BOPO merupakan rasio yang digunakan untuk mengukur tingkat efisiensi dan kemampuan perbankan dalam melakukan kegiatan operasional perusahaan. Semakin besar biaya operasional yang dikeluarkan maka dapat mendorong bank untuk meningkatkan prosentase bagi hasil, sehingga debitur akan kesulitan mengembalikan dana (Gunawan dan Sudaryanto, 2016) ${ }^{2}$. Biaya operasional yang tinggi akan bedampak pada pendapatan perbankan. Hal ini menyebabkan pendapatan bank menurun dan berpengaruh pada jumlah dana yang disalurkan melalui pembiayaan. Penelitian yang dilakukan oleh Jayanti (2013), Gunawan dan Sudaryanto (2016), dan Adisaputra (2012) menyatakan bahwa BOPO berpengaruh terhadap $\mathrm{NPF}^{3}$. sedangkan penelitian yang

\footnotetext{
1 Irham Fahmi. 2014 (Pengantar Perbankan Teori \& Aplikasi. Bandung: Alfabeta) Hal.104

2 Andreas Gunawan P. dan Budi Sudaryanto. 2016. analisis pengaruh performance, size, inefisiensi, capital, dan dana pihak ketiga terhadap non performing loan. ISSN (Online): 2337-3792

${ }^{3}$ Karunia Dwi Jayanti. 2013. Analisis Faktor-Faktor Yang Mempengaruhi Non-Performing Loan (Studi Pada Bank Umum Konvensional yang Go Public di Indonesia Periode 2008-2012). Skripsi Universitas Diponogoro Semarang.
} 
dilakukan oleh Destiana (2018) dan Permatasari (2019) menunjukkan BOPO tidak berpengaruh terhadap NPF4.

Faktor kedua yang mempengaruhi NPF adalah Financing to Deposit Ratio (FDR). Menurut Muhammad (2015;193) Rasio FDR merupakan rasio yang digunakan untuk mengukur perbandingan pembiayaan terhadap dana pihak ketiga (DPK) ${ }^{5}$. Jumlah dana yang disalurkan bank dalam bentuk pembiayaan kepada para nasabah berhubungan dengan tuntutan untuk memanfaatkan kelebihan likuiditas. Dana yang menganggur terlalu banyak pada bank dinilai bank tidak dapat memanfaatkan uangnya dengan baik. Besarnya dana pihak ketika berpengaruh signifikan terhadap jumlah pembiayaan yang akan disalurkan kepada masyarakat. Semakin tinggi jumlah pembiayaan yang disalurkan, maka akan berisiko adanya nasabah yang tidak dapat memenuhi kewajibannya terhadap bank. FDR adalah rasio yang menilai perbandingan antara pembiayaan yang disalurkan dan besarnya dana yang dihimpun oleh bank yang berasal dari DPK. Rasio FDR dinilai mampu menggambarkan peluang munculnya pembiayaan. Artinya semakin tinggi Rasio FDR, maka semakin tinggi pula NPF, dan semakin kecil FDR akan menyebabkan NPF menurun. Gunawan dan Sudaryanto ( 2016), Destiana (2018), Permatasari (2019), Adisaputra (2012), Vanni dan Rokhman (2017) menunjukkan bahwa FDR

Andreas Gunawan P. dan Budi Sudaryanto. 2016. analisis pengaruh performance, size, inefisiensi, capital, dan dana pihak ketiga terhadap non performing loan. ISSN (Online): 2337-3792.

Iksan Adisaputra. 2012. Analisis Faktor-Faktor Yang Mempengaruhi Non Performing Loan Pada Pt. Bank Mandiri (Persero) TBK. Skripsi Universitas Hasanuddin Makasar.

4 Rina Destiana. 2018. Determinan Pembiayaan Bermasalah Pada Bank Syariah Di Indonesia. JRKA Volume 4 Isue 1, Februari 2018: 53-63.

Nyimas Aisah Permatasari. Pengaruh Bank Size, Car, Bopo Dan Ldr Terhadap Npl Dengan Inflasi Sebagai Moderasi Pada Perbankan Di Bei. Artikel Ilmiah Sekolah Tinggi Ilmu Ekonomi Perbanas Surabaya

5 Muhammad. 2015. Manajemen Dana Bank Syariah. Edisi Kedua. Jakarta: Rajawali Pers. Hal; 193 
berpengaruh signifikan terhadap NPF6. Sedangkan Rosidah (2017) dan Jayanti (2013) menyatakan bahwa FDR tidak berpengaruh signifikan terhadap NPF7.

Solusi yang dapat ditawarkan dalam menanggulangi risiko kredit adalah dangan cara bank menyediakan dana untuk mengambangkan perbankan dan sebagai cadangan apabila terjadi risiko yang terjadi selama kegiatan operasional bank berjalan. Penyediaan dana tersebut dapat dihitung dengan menggunakan rasio Capital Adequacy Ratio (CAR). Menurut Wardiah (2013; 295) Capital Adequacy Ratio (CAR) adalah rasio kecukupan modal bank atau disebut juga kemampuan bank dalam permodalan yang ada untuk menutup kemungkinan kerugian dalam pembiayaan dan perdagangan surat-surat berharga ${ }^{8}$. Rasio CAR dapat memperlihatkan seberapa banyak Asset bank yang mengandung risiko (pembiayaan, penyertaan, surat berharga, tagihan pada bank lain) ikut dibiayai dari modal sendiri disamping memperoleh dana-dana dari sumber-sumber di luar bank, seperti dana dari masyarakat, pinjaman dan lainlain (Dendawijaya, 2003) ${ }^{9}$. Tingginya modal yang diperoleh oleh bank mengidentifikasikan bahwa bank akan mudah untuk membiayai Aset yang mengandung risiko. Jika penyaluran pembiayaan tidak disertai dengan kecukupan modal, akan menimbulkan pembiayaan bermasalah. Artinya, semakin tinggi rasio CAR akan dapat menekan risiko

6 Kartika Marella Vanni dan Wahibur Rokhman. 2017. Analisis FaktorFaktor Yang Mempengaruhi Non Performing Financing Pada Perbankan Syariah Di Indonesia Tahun 2011-2016. EQUILIBRIUM: Jurnal Ekonomi Syariah Volume 5, Nomor 2, 2017, 306 - 319.

7 Euis Rosidah. 2017. Pengaruh Financing To Deposit Ratio Terhadap Non Performing Financing Perbankan Syariah di Indonesia. Jurnal Akuntansi Vol 12, Nomor 2.

8 Mia Lasmi Wardiah. 2013. Dasar-dasar Perbankan. Bandung : Pustaka Setia. Hal;295

9 Lukman Dendawijaya. 2003. Manajemen Perbankan. Jakarta : Ghalia Indonesia. 
pembiayaan yang dihadapi oleh bank (Diyanti dan widyarti 2012) ${ }^{10}$. Penelitian yang dilakukan oleh Permatasari (2019), Destiana (2018) dan Adisaputra (2012) menunjukkan bahwa CAR berpengaruh signifikan terhadap NPF11. Sedangkan Gunawan dan Sudaryanto ( 2016) dan Jayanti (2013) menyatakan hal yang berbeda, yakni CAR tidak berpengaruh signifikan terhadap NPF12.

Berdasarkan uraian di atas, Rumusan masalah pada penelitian ini adalah apakah faktor-faktor yang mempengaruhi risiko pembiayaan bank umum syariah di Indonesia? Adapun tujuan dari penelitian ini adalah untuk mengetahu faktor-faktor yang mempengaruhi risiko pembiayaan pada bank umum syariah, khususnya pada rasio BOPO, FDR dan CAR.

\section{KAJIAN PUSTAKA \\ Risiko Pembiayaan}

Risiko Pembiayaan menurut Wardiah (2013:141) adalah risiko yang timbul sebagai akibat kegagalan pihak memenuhi kewajibannya ${ }^{13}$. Risiko pembiayaan merupakan keadaan dimana debitur baik individu maupun perusahaan tidak dapat membayar kembali pokok hutang beserta bagi

10 Nyimas Aisah Permatasari. Pengaruh Bank Size, Car, Bopo Dan Ldr Terhadap Npl Dengan Inflasi Sebagai Moderasi Pada Perbankan Di Bei. Artikel Ilmiah Sekolah Tinggi Ilmu Ekonomi Perbanas Surabaya

11 Rina Destiana. 2018. Determinan Pembiayaan Bermasalah Pada Bank Syariah Di Indonesia. JRKA Volume 4 Isue 1, Februari 2018: 53-63.

Iksan Adisaputra. 2012. Analisis Faktor-Faktor Yang Mempengaruhi Non Performing Loan Pada Pt. Bank Mandiri (Persero) TBK. Skripsi Universitas Hasanuddin Makasar.

12 Andreas Gunawan P. dan Budi Sudaryanto. 2016. analisis pengaruh performance, size, inefisiensi, capital, dan dana pihak ketiga terhadap non performing loan. ISSN (Online): 2337-3792.

Iksan Adisaputra. 2012. Analisis Faktor-Faktor Yang Mempengaruhi Non Performing Loan Pada Pt. Bank Mandiri (Persero) TBK. Skripsi Universitas Hasanuddin Makasar.

13 Mia Lasmi Wardiah. 2013. Dasar-dasar Perbankan. Bandung : Pustaka Setia. Hal;141 
hasil yang telah disepakati oleh pihak bank dan nasabah. Pembiayaan merupakan produk utama perbankan syariah dalam menghasilkan keuntungan. Apabila perbankan mengalami pembiayaan macet yang tinggi, maka perbankan sedang berada pada risiko kegagalan yang tinggi. Risiko pembiayaan merupakan penyebab utama kegagalan bank, oleh sebab itu, risiko ini harus dikelola dengan baik. Pengukuran risiko pembiayan pada bank syariah dapat menggunakan rasio Non Performing Financing (NPF). NPF digunakan untuk menilai persentase total pembiayaan bermasalah terhadap total pembiayaan yang disalurkan oleh bank. Semakin kecil rasio NPF maka risiko yang akan dihadapi bank akan kecil pula, dan sebaliknya. Rumus untuk menghitung Non Performing financing menurut Chen (2014:8) ${ }^{14}$ adalah:

$$
N P F=\frac{\text { Total NPF }}{\text { Total Loans }} \times 100 \%
$$

Peraturan Bank Indonesia NOMOR 17/11/PBI/2015 menjelaskan bahwa standar yang ditetapkan Bank Indonesia untuk rasio NPF maksimal adalah 5\%. Artinya, apabila rasio NPF menunjukkan nilai kurang dari 5\%, maka risiko pembiayaan yang dialami oleh bank adalah kecil. Sebaliknya, apabila rasio NPF menunjukkan angka dilebih dari 5\%. Artinya, bank sedang berada dalam risiko yang besar.

\section{Beban Operasional terhadap Pendapatan Operasional (BOPO)}

Beban operasional terhadap pendapatan operasional merupakan rasio yang digunakan untuk mengukur tingkat risiko operasional yang dihadapi oleh bank. Rasio ini mengukur tingkat efisiensi dan kemampuan perbankan dalam melakukan kegiatan operasional perusahaan. Semakin besar beban operasional yang dikeluarkan oleh perbankan maka

14 Chen, Sandy. 2014. Integrated Bank Analysis and Valuation. New York: Palgrave Macmillan. 
dapat mendorong bank untuk meningkatkan prosentase bagi hasil, sehingga nasabah akan kesulitan mengembalikan dana yang telah dipinjam kepada bank. Beban operasional meliputi beban bunga, beban kerugian komitmen dan kontijensi, beban penghapusan aktiva produktif dan beban lain-lain yang berhubungan dengan kegiatan usaha perbankan, sedangkan pendapatan operasional meliputi pendapatan bagi hasil, komisi dan provisi, pendapatan transaksi valuta asing dan pendapatan operasional lainnya. Semakin tinggi rasio BOPO menunjukkan bahwa semakin tinggi pula risiko operasional yang dihadapi oleh bank. Nilai BOPO yang tinggi menunjukkan bahwa beban operasional bank tinggi. Rumus yang digunakan untuk menghitung BOPO menurut Sulhan dan Siswanto $(2008 ; 87)^{15}$ adalah;

$$
\text { BOPO }=\frac{\text { Beban operasional }}{\text { pendapatan operasional }} \times 100 \%
$$

Peraturan Bank Indonesia NOMOR 17/11/PBI/2015 menjelaskan bahwa standar yang ditetapkan Bank Indonesia untuk rasio BOPO adalah maksimal 85\%. Artinya apabila nilai BOPO lebih dari angka tersebut, pengelolaan keuangan bank tidak efisien. Nilai BOPO diatas 85\% mengidentifikasikan bahwa beban operasional yang dikeluarkan bank sangat tinggi, sehingga hal ini mendorong bank untuk meningkatkan penghasilan dari transaksi bagi hasil. Tuntutan beban operional yang terlalu tinggi inilah yang menyebabkan bank menaikkan persentasi bagi hasil, dan menyebabkan nasabah kesulitan memenuhi kewajibannya terhadap perbankan. Berdasarkan uraian tersebut, maka hipotesis dalam penelitian ini adalah;

$\mathrm{H}_{1} \quad$ : BOPO berpengaruh signifikan terhadap NPF BUS

\section{Financing to Deposit Ratio (FDR)}

15 Sulhan dan Siswanto, Ely. 2008. Manajemen Bank Konvensional Dan Syariah. Malang: UIN-Malang press. Hal;87 
Financing to Deposit Ratio (FDR) adalah rasio yang menunjukkan kesehatan bank dalam pemberian pembiayaan (Muhammad, 2015:253) ${ }^{16}$. Rasio ini digunakan untuk mengetahui jumlah dana pihak ketiga yang dimanfaatkan dalam penyaluran pembiayaan. Jumlah dana yang disalurkan bank dalam bentuk pembiayaan kepada para nasabah berhubungan dengan tuntutan untuk memanfaatkan kelebihan likuiditas. Menurut Wardiah (2013:181) ${ }^{17}$, likuiditas bank adalah kemampuan bank untuk memenuhi kewajibannya, terutama kewajiban jangka pendek. Dari sudut aset, likuiditas adalah kemampuan untuk mengubah seluruh aset menjadi bentuk tunai (cash), sedangkan dari sudut pasiva, likuiditas adalah kemampuan untuk memenuhi kebutuhan dana melalui peningkatan portofolio liabilitas. Likuiditas diperlukan bank untuk memberikan kompensasi fluktuasi neraca yang terduga dan tidak terduga serta menyediakan dana untuk pertumbuhan.

Dana yang menganggur terlalu banyak pada bank dinilai bank tidak dapat memanfaatkan uangnya dengan baik. Besarnya dana pihak ketika berpengaruh signifikan terhadap jumlah pembiayaan yang akan disalurkan kepada masyarakat. Semakin tinggi jumlah pembiayaan yang disalurkan, maka akan berisiko adanya nasabah yang tidak dapat memenuhi kewajibannya terhadap bank. FDR adalah rasio yang menilai perbandingan antara pembiayaan yang disalurkan dan besarnya dana yang dihimpun oleh bank yang berasal dari DPK. Rasio FDR dinilai mampu menggambarkan peluang munculnya pembiayaan. Artinya semakin tinggi Rasio FDR, maka semakin tinggi pula NPF, dan semakin kecil FDR akan

\footnotetext{
${ }^{16}$ Muhammad. 2015. Manajemen Dana Bank Syariah. Edisi Kedua. Jakarta: Rajawali Pers. Hal; 253

17 Mia Lasmi Wardiah. 2013. Dasar-dasar Perbankan. Bandung : Pustaka Setia. Hal;181
} 
menyebabkan NPF menurun. Rumus yang digunakan untuk menghitung FDR menurut Kasmir $(2015 ; 226)^{18}$ adalah;

$$
F D R=\frac{\text { Total Pembiayaan }}{\text { Total dana pihak ketiga }} X 100 \%
$$

Peraturan Bank Indonesia NOMOR 17/11/PBI/2015 menjelaskan bahwa standar yang ditetapkan Bank Indonesia untuk rasio FDR adalah 85\% sampai dengan 110\%. Artinya apabila nilai FDR kurang dari atau lebih dari angka tersebut, pengelolaan keuangan bank tidak efisien. Berdasarkan uraian tersebut, maka hipotesis dalam penelitian ini adalah;

$\mathrm{H}_{2}$ : FDR berpengaruh signifikan terhadap NPF BUS

\section{Capital Adequacy Ratio (CAR)}

Capital Aduquecy Ratio (CAR) adalah rasio kecukupan modal yang digunakan untuk menampung selaga risiko keuangan yang mungkin akan terjadi pada bank. CAR merupakan rasio yang digunakan Bank Indonesia (BI) dalam upaya menentukan penyediaan modal minimum yang harus dimiliki oleh bank. Semakin tinggi CAR maka semakin besar pula modal yang dimiliki. Banyaknya modal mengidentifikasikan bahwa penyaluran pembiayaan juga akan mengalami peningkatan, sehingga risiko terjadinya pembiayaan gagal bayar juga ikut meningkat. Semakin tinggi modal yang dimiliki bank maka akan semakin mudah bagi bank untuk membiayai aktiva yang mengandung risiko (Jayanti, 2013) ${ }^{19}$. Jika penyaluran pembiayaan tidak disertai dengan kecukupan modal, akan menimbulkan pembiayaan bermasalah. rumus yang digunakan untuk menghitung CAR adalah;

$$
C A R=\frac{\text { Total Modal }}{\text { Aktiva tertimbang menurut risiko }} \times 100 \%
$$

\footnotetext{
${ }^{18}$ Kasmir. 2015. Analisis Laporan Keuangan. Cetakan ke-delapan. Jakarta: PT. Raja Grafindo Persada; Hal.226

${ }^{19}$ Karunia Dwi Jayanti. 2013. Analisis Faktor-Faktor Yang Mempengaruhi NonPerforming Loan (Studi Pada Bank Umum Konvensional yang Go Public di Indonesia Periode 2008-2012). Skripsi Universitas Diponogoro Semarang
} 
Peraturan Bank Indonesia NOMOR 17/11/PBI/2015 menjelaskan bahwa standar yang ditetapkan Bank Indonesia untuk rasio CAR minimum adalah 8\%. Artinya apabila nilai CAR kurang dari angka tersebut, maka perbankan tidak memiliki penyediaan modal yang cukup, sehingga bank sedang berada dalam risiko yang tinggi. Berdasarkan uraian tersebut, maka hipotesis dalam penelitian ini adalah $\mathrm{H}_{3} \quad$ : CAR berpengaruh signifikan terhadap NPF BUS

\section{METODE PENELITIAN}

Penelitian ini dirancang untuk mengetahui faktorfaktor yang mempengaruhi risiko pembiayaan pada bank umum syariah. Risiko pembiayaan dalam hal ini diukur dengan rasio NPF yang akan berperan sebagai variabel dependen, adapun variabel independen yang digunakan adalah BOPO, FDR, dan CAR. Alat analisis yang digunakan dalam penelitian ini adalah Regresi Linear berganda yang akan di olah pada aplikasi SPSS. Adapun Model analisis yang digunakan adalah;

$$
Y=a+b_{1} x_{1}+b_{2} x_{2}+b_{3} x_{3}+e
$$

Keterangan:

$\mathrm{Y}$

a

$\mathrm{b}$

$\mathrm{X}_{1}$

$\mathrm{X}_{2}$

$\mathrm{X}_{3}$

$\mathrm{e}$
: NPF

: Konstanta

: Koefisien parameter

: BOPO

: FDR

: CAR

: Standart eror

Jenis data yang digunakan adalah data sekunder yang berasal dari website masing-masing perbankan yang akan dijadikan sampel penelitian. Data yang diperoleh berupa laporan keuangan tahunan yang telah dipublikasikan. 
selanjutnya akan dihitung berdasarkan rasio-rasio yang digunakan dalam penelitian.

Populasi dalam penelitian ini adalah seluruh Bank Umum Syariah (BUS) yang terdaftar pada OJK, yaitu sejumlah 14 bank. Adapun teknik pengambilan sampel adalah menggunakan metode purposive sampling, dengan kriteria;

1. Bank Umum Syariah (BUS) yang menerbitkan laporan keuangan secara rutin selama periode penelitian, yakni tahun 2015 sampai dengan tahun 2019.

2. BUS yang menyediakan data secara lengkap, terkait data penelitian

3. BUS yang mempunyai kinerja keuangan setara dengan BUS lainnya. artinya dalam periode penelitian BUS tidak sedang menghadapi masalah keuangan yang buruk.

Berdasarkan kriteria yang ditetapkan, maka BUS yang dapat dijadikan sampel berjumlah 6 (enam) bank, diantaranya; PT. Bank Syariah Mandiri, PT. Bank BCA Syariah, PT. Bank BNI syariah, PT. Bank Muamalat, PT. Bank Victorya Syariah dan PT. Bank Bukopin Syariah.

\section{HASIL DAN PEMBAHASAN}

\section{HASIL}

Alat analisis yang digunakan dalam penelitian ini adalah regresi linear berganda yang diolah melalui aplikasi SPSS Ver. 20. Nilai signifikansi yang digunakan pada penelitian ini adalah 5\%. Artinya apabila signifikansi menunjukkan angka $\leq 0,05$ maka variabel independen berpengaruh signifikan terhadap variabel dependen. Sebaliknya, apabila signifikansi menunjukkan angka $\geq 0,05$ maka variabel independend tidak berpengaruh terhadap variabel dependent. Adapun hasil analisis yang telah dilakukan disajikan pada tabel 2 .

Tabel 2. Hasil Analisis regresi linear berganda 


\section{Coefficients $^{a}$}

\begin{tabular}{|c|c|c|c|c|c|c|}
\hline \multirow[t]{2}{*}{ Model } & & \multicolumn{2}{|c|}{$\begin{array}{l}\text { Unstandardized } \\
\text { Coefficients }\end{array}$} & \multirow{2}{*}{$\begin{array}{l}\text { Standardized } \\
\text { Coefficients } \\
\text { Beta }\end{array}$} & & \multirow[t]{2}{*}{ Sig. } \\
\hline & & B & Std. Error & & & \\
\hline \multirow{4}{*}{1} & (Constant) & $-2,664$ & 2,000 & & $-1,332$ & 0,194 \\
\hline & ВОРО & 0,099 & 0,021 & 0,665 & 4,821 & 0,000 \\
\hline & FDR & $-0,031$ & 0,027 & $-0,158$ & $-1,155$ & 0,259 \\
\hline & CAR & $-0,085$ & 0,027 & $-0,394$ & $-3,126$ & 0,004 \\
\hline
\end{tabular}

a. Dependent Variable: NPF

\section{Sumber; SPSS (data diolah)}

Berdasarkan hasil pengujian yang disajikan pada tabel 2, dapat diketahui bahwa BOPO berpengaruh positif signifikan terhadap NPF. Hal ini dapat dilihat dari nilai signifikansi yang menunjukkan angka 0,000. Hasil ini mengidentifikasikan bahwa semakin tinggi BOPO maka akan mempengaruhi tingginya NPF BUS dan Hipotesis yang menyatakan BOPO berpengaruh signifikan terhadap NPF dapat diterima.

Hasil pengujian FDR terhadap NPF menunjukkan nilai signifikansi sebesar 0,259. Nilai ini lebih dari 0,05. Artinya pergerakan rasio FDR tidak mempengaruhi pembiayaan bermasalah pada BUS syariah. Hal ini dapat dikatakan bahwa FDR bukan merupakan faktor yang mempengaruhi adanya pembiayaan macet dan hipotesis yang menyatakan FDR berpengaruh terhadap NPF ditolak.

Hasil pengujian rasio CAR terhadap NPF menunjukkan nilai signifikasi sebesar 0,04. nilai ini leboh kecil dari 0,05 dan beta menunjukkan angka negatif $-0,394$. Artinya, rasio CAR berpengaruh negatif signifikan terhadap NPF. Semakin tinggi CAR maka akan menyebabkan semakin rendahnya rasio NPF. Sebaliknya, Rasio CAR yang rendah akan menyebabkan pembiayaan bermasalah semakin tinggi. Hal ini berarti hipotesis yang menyatakan CAR berpengaruh terhadap NPF dapat diterima. 


\section{PEMBAHASAN}

\section{Pengaruh BOPO terhadap NPF}

Hasil pengujian menunjukkan bahwa BOPO berpengaruh positif signifikan terhadap NPF. Artinya, semakin tinggi BOPO akan menyebabkan NPF semakin tinggi pula. BOPO yang tinggi mengidentifikasikan bahwa beban operasional yang dikeluarkan perbankan sangat tinggi dan tidak sesuai dengan pendapatan operasional yang telah diperoleh oleh perbankan. Tingginya beban operasional perbankan menuntut bank untuk meningkatkan pendapatan, agar beban-beban yang telah dikeluarkan dapat ditutupi dengan pendapatan yang akan dihasilkan oleh perbankan. pendapatan utama lembaga keuangan bank berasal dari nisbah bagi hasil yang telah disepakati oleh pihak perbankan dan nasabah. Adanya tuntutan ini menyebabkan bank menaikkan persentase bagi hasil yang akan disepakati oleh para nasabah yang mengajukan pembiayaan. Tingginya standar bagi hasil inilah yang menyebabkan para nasabah kesulitan dalam membayar kewajibannya kepada bank. Sehingga banyak nasabah yang gagal bayar dan menyebabkan rasio NPF tinggi.

Penemuan ini didukung oleh beberapa penelitian terdahulu diantaranya Penelitian yang dilakukan oleh Jayanti (2013), Gunawan dan Sudaryanto (2016), dan Adisaputra (2012) menunjukkan hasil penelitian rasio BOPO berpengaruh signifikan terhadap NPF20.

\footnotetext{
${ }^{20}$ Karunia Dwi Jayanti. 2013. Analisis Faktor-Faktor Yang Mempengaruhi NonPerforming Loan (Studi Pada Bank Umum Konvensional yang Go Public di Indonesia Periode 2008-2012). Skripsi Universitas Diponogoro Semarang.

Andreas Gunawan P. dan Budi Sudaryanto. 2016. analisis pengaruh performance, size, inefisiensi, capital, dan dana pihak ketiga terhadap non performing loan. ISSN (Online): 2337-3792.

Iksan Adisaputra. 2012. Analisis Faktor-Faktor Yang Mempengaruhi Non Performing Loan Pada Pt. Bank Mandiri (Persero) TBK. Skripsi Universitas Hasanuddin Makasar.
} 


\section{Pengaruh FDR terhadap NPF}

Hasil pengujian menunjukkan bahwa FDR tidak berpengaruh signifikan terhadap NPF. Artinya, tinggi dan rendahnya rasio FDR tidak mempengaruhi pembiaayaan macet perbankan. FDR adalah rasio yang digunakan untuk mengetahui seberapa efektif dana pihak ketiga disalurkan dalam bentuk pembiayaan. Dana yang terlalu banyak menganggur, dinilai tidak baik karena dana tersebut tidak dapat menghasilkan keuntungan bagi perusahaan. Sebaliknya, dana yang terlalu sedikit akan menyebabkan perusahaan tidak likuid. Sehingga dana yang berada dalam perusahaan harus cukup. Tinggi dan rendahnya rasio FDR tidak berpengaruh terhadap NPF perbankan, karena setiap nasabah yang akan melaksanakan pembiayaan melalui tahap 5C dalam pemberian pembiayaan perbankan. Adapun tahap 5C yang dimaksud adalah; Character, Capacity, Capital, Condition, Collateral. Jika nasabah telah memenuhi 5 prinsip tersebut, maka BUS akan mengabulkan permintaan kerjasama antara bank dengan nasabah yang bersangkutan. Sehingga, banyaknya pembiayaan yang disalurkan kepada nasabah tidak berpengaruh terhadap pembiyaan macet perbankan.

Hasil penelitian ini mendukung penelitian yang dilakukan oleh Rosidah (2017) dan Jayanti (2013) yang menyatakan bahwa FDR tidak berpengaruh signifikan terhadap NPF21. Artiya, kondisi apapun yang dialami oleh bank terkait dangan likuiditas, tidak mempengaruhi adanya nasabah yang gagal memenuhi kewajibannya terhadap perbankan.

\section{Pengaruh CAR terhadap NPF}

\footnotetext{
${ }^{21}$ Karunia Dwi Jayanti. 2013. Analisis Faktor-Faktor Yang Mempengaruhi NonPerforming Loan (Studi Pada Bank Umum Konvensional yang Go Public di Indonesia Periode 2008-2012). Skripsi Universitas Diponogoro Semarang.

Euis Rosidah. 2017. Pengaruh Financing To Deposit Ratio Terhadap Non Performing Financing Perbankan Syariah di Indonesia. Jurnal Akuntansi Vol 12, Nomor 2.
} 
Hasil pengujian hipotesis menunjukkan bahwa CAR berpengaruh negatif signifikan terhadap NPF. Artinya, CAR dan NPF memiliki hubungan yang berlawanan, semakin tinggi CAR maka semakin rendah rasio NPF. Rasio CAR yang tinggi menunjukkan bahwa bank mempunyai kesediaan modal yang cukup untuk mengantisipasi adanya risiko keuangan yang terjadi, sehingga hal ini akan mengurangi adanya risiko pembiayaan, yang dalam hal ini di ukur dengan NPF. CAR merupakan rasio yang digunakan untuk menampung adanya berbagai kemungkinan risiko keuangan yang terjadi, semakin tinggi CAR berarti semakin tinggi pula modal yang dimiliki oleh perbankan. Hal ini menunjukkan bahwa bank berada jauh dari risiko pembiayaan bermsalah. Hasil temuan ini didukung oleh beberapa penelitian terdahulu, diantaranya Permatasari (2019), Destiana (2018) dan Adisaputra (2012) menunjukkan bahwa CAR berpengaruh signifikan terhadap $\mathrm{NPF}^{22}$.

\section{KESIMPULAN}

Penelitian ini dilakukan untuk mengetahui faktor-faktor yang mempengaruhi risiko pembiayaan pada Bank Umum Syariah. Risiko pembiayaan diukur dengan rasio Non Performing Financing yang berperan sebagai variabel dependen, sedangkan variabel independen yang digunakan adalah Beban Operasional terhadap Pendapatan Operasional (BOPO), Financing to Deposit Ratio (FDR) dan Capital Aduquecy Ratio

\footnotetext{
${ }^{22}$ Nyimas Aisah Permatasari. Pengaruh Bank Size, Car, Bopo Dan Ldr Terhadap Npl Dengan Inflasi Sebagai Moderasi Pada Perbankan Di Bei. Artikel IImiah Sekolah Tinggi Ilmu Ekonomi Perbanas Surabaya.

Rina Destiana. 2018. Determinan Pembiayaan Bermasalah Pada Bank Syariah Di Indonesia. JRKA Volume 4 Isue 1, Februari 2018: 53-63.

Iksan Adisaputra. 2012. Analisis Faktor-Faktor Yang Mempengaruhi Non Performing Loan Pada Pt. Bank Mandiri (Persero) TBK. Skripsi Universitas Hasanuddin Makasar.
} 
(CAR). Berdasarkan hasil analisis yang telah dilakukan, maka dapat disimpulkan bahwa;

1) BOPO berpengaruh positif signifikan terhadap NPF. Artinya semakin tinggi rasio BOPO maka semakin tinggi pula risiko pembiayaan Bank Umum Syariah.

2) FDR tidak berpengaruh signifikan terhadap NPF. Artinya, besar dan kecilnya rasio FDR tidak berpengaruh terhadap risiko pembiayaan Bank Umum Syariah.

3) CAR berpengaruh negatif signifikan terhadap NPF. Artinya, semakin tinggi CAR maka risiko pembiayaan akan semakin menurun.

\section{DAFTAR PUSTAKA}

Andreas Gunawan P. dan Budi Sudaryanto. 2016. analisis pengaruh performance, size, inefisiensi, capital, dan dana pihak ketiga terhadap non performing loan. ISSN (Online): 2337-3792

Anin Diyanti, Endang Tri Widyarti. 2012. Analisis Pengaruh Faktor Internal dan Eksternal Terhadap Terjadinya Non Performing Loan (Studi Kasus pada Bank Umum Konvensional yang Menyediakan Layanan Kredit Kepemilikan Rumah Periode 2008-2011).

Chen, Sandy. 2014. Integrated Bank Analysis and Valuation. New York: Palgrave Macmillan.

Dendawijaya, Lukman. 2003. Manajemen Perbankan. Jakarta : Ghalia Indonesia

Euis Rosidah. 2017. Pengaruh Financing To Deposit Ratio Terhadap Non Performing Financing Perbankan Syariah di Indonesia. Jurnal Akuntansi Vol 12, Nomor 2.

Fahmi, Irham. 2014. Pengantar Perbankan Teori \& Aplikasi. Bandung: Alfabeta. 
https://www.ojk.go.id/id/kanal/syariah/data-dan-

statistik/statistik-perbankan-syariah/default.aspx

(data statistik OJK diakses pada tanggal 20 April 2021)

Iksan Adisaputra. 2012. Analisis Faktor-Faktor Yang Mempengaruhi Non Performing Loan Pada Pt. Bank Mandiri (Persero) TBK. Skripsi Universitas Hasanuddin Makasar

Kartika Marella Vanni dan Wahibur Rokhman. 2017. Analisis Faktor-Faktor Yang Mempengaruhi Non Performing Financing Pada Perbankan Syariah Di Indonesia Tahun 2011-2016. EQUILIBRIUM: Jurnal Ekonomi Syariah Volume 5, Nomor 2, 2017, 306 - 319 P-ISSN: 23550228, E-ISSN: 2502-8316.

Karunia Dwi Jayanti. 2013. Analisis Faktor-Faktor Yang Mempengaruhi Non-Performing Loan (Studi Pada Bank Umum Konvensional yang Go Public di Indonesia Periode 2008-2012). Skripsi Universitas Diponogoro Semarang.

Kasmir. 2015. Analisis Laporan Keuangan. Cetakan kedelapan. Jakarta: PT. Raja Grafindo Persada.

Muhammad. 2015. Manajemen Dana Bank Syariah. Edisi Kedua. Jakarta: Rajawali Pers.

Nyimas Aisah Permatasari. Pengaruh Bank Size, Car, Bopo Dan Ldr Terhadap Npl Dengan Inflasi Sebagai Moderasi Pada Perbankan Di Bei. Artikel Ilmiah Sekolah Tinggi Ilmu Ekonomi Perbanas Surabaya.

Rina Destiana. 2018. Determinan Pembiayaan Bermasalah Pada Bank Syariah Di Indonesia. JRKA Volume 4 Isue 1, Februari 2018: 53-63.

Siahaan, Hinsa. 2009. Manajemen Risiko Pada Perusahaan Birokrasi. Cetakan Kedua. Jakarta: PT. Elex Media Komputindo. 
Sulhan dan Siswanto, Ely. 2008. Manajemen Bank Konvensional Dan Syariah. Malang: UIN-Malang press.

Wardiah, Mia Lasmi. 2013. Dasar-dasar Perbankan. Bandung : Pustaka Setia 